\title{
CLAY BRICK WASTE: NEW FILLER TO NATURAL RUBBER COMPOSITE
}

\author{
Lucas Neves $^{1 *}$, Fábio F. G. Paiva ${ }^{1}$, Giovani B. Bacarin ${ }^{1}$, Flávio Camargo Cabrera ${ }^{1}$ and \\ Aldo E. Job ${ }^{1}$ \\ ${ }^{1}$ Laboratório de Química, Física e Biologia, Universidade Estadual Paulista - UNESP, 19060-900, Presidente \\ Prudente, SP, Brasil.
}

Received 8 October 2019; received in revised form 10 January 2021; accepted 10 February 2021

\begin{abstract}
The development of urban cities increases the amount of construction and demolition waste, such as ceramic materials, mainly clay bricks, and consequently, generates cost for the management and environmental disposal due to the few routes to recycle or reuse them. Here, it is proposed a new approach to reuse clay bricks waste (CB) composed by red ceramic as reinforcement filler to natural rubber (NR) composites. It was verified that the residue is mostly composed of silicon, which is a filler widely used in rubber industry as $\mathrm{SiO} 2$, to mechanically reinforce composites. Tensile strength showed an increment around $16 \%$ when $20 \mathrm{phr}$ of $\mathrm{CB}$ waste was added to the natural rubber (reaching 12,4 MPa). In addition, composites with $10 \mathrm{phr}$ of waste showed great abrasion resistance and the hardness property increased as CB waste was added. The results indicate that the residue can be used as a possible filler in natural rubber products.
\end{abstract}

Keywords: clay bricks; composites; natural rubber; reuse.

(C) 2021 Journal of Urban and Environmental Engineering (JUEE). All rights reserved.

\footnotetext{
* Correspondence to: Flavio Camargo Cabrera. E-mail: flavioccabrera@yahoo.com.br
} 


\section{INTRODUCTION}

The development of urban cities has generated large amounts of construction and demolition waste. Every year, it is estimated the production of 3 billion tons of construction and demolition waste around the world (Akhtar, 2018), being 85\% related to concrete, ceramics and masonry wastes. Based on the classification of NBR 10004/04 (NBR standard, 2004), this kind of residue is framed on 2B class i.e. inert (Monier, 2018). However, the high amount of residues became an environmental issue inferring costs to management and landfill disposal. Thus, clay bricks waste are intensively studied for the replacement of fine aggregate (partly or totally) in cementitious (Amin, 2015), mortar (Dang, 2018) and concrete materials (Zong, 2014). Currently, several researches evaluated the effectiveness of hybrid-type binders of a red clay brick waste production, which reduced around $30 \%$ of Portland cement and showed great compressive strengths (102 $\mathrm{MPa}$ at 28 days) (Robayo-Salazar,2017). The substitution of fine aggregates was also studied in concrete properties, with good replacement levels $(10 \%, 20 \%$, and $30 \%)$. The results also revealed similar density values around $2400-2500 \mathrm{~kg} / \mathrm{m}^{3}$ and a decrease in early-age strength (Mohammed, 2017).

As an alternative method to reuse and recycle most industrial and organic wastes, the application of polymeric composites with residues as reinforcement fillers has grown interest among the researchers. Composites using pineapple fiber (Pittayavinai, 2016), sugarcane bagasse fiber (Paiva, 2018), jute fiber (Huang, 2017), leather waste (Garcia, 2015), rice husk ash (Pongdong, 2016), blast furnace slag (Patnaik, 2018), phosphogypsum (Essabir, 2017), glass fiber (Novais, 2017), marble (Fiore, 2018), and mineral wool (Väntsi, 2014), have been widely reported. Among the polymers, research involving the use of natural rubber for artificial muscles (Hawkes, 2016), microfluidic matrix (Cabrera, 2014), antibacterial composites (Chen, 2018), green synthesis (Cabrera, 2013) and, solventsensitive memory materials (Dong, 2016) as well as the recycling of residues as fillers (Barrera, 2016) and (Zefeng, 2018) make the elastomer an interesting way to reuse clay brick residues. Here, we demonstrate a new approach to reuse clay bricks waste (CB), composed by red ceramic, as a reinforcement filler to natural rubber (NR) composites. The mechanical, morphological and structural properties of the composites were investigated in order to avoid incorrect disposal and to generate a new eco-friendly material.

\section{MATERIALS AND METHODS}

Clay brick waste was collected from a construction residue in the city of Presidente Prudente, São Paulo, Brazil. Natural rubber of Crepe Brazilian Clear (CCB) type was provided by DLP Industry and commerce of rubber and artifacts, being used as the polymer matrix with Mooney viscosity higher than 98 . Zinc oxide was provided by LABSYNTH Laboratory Products, Diadema, SP, Brazil and stearic acid by Jand Chemistry Industry and Commerce of Products Chemistry Ltda, Jandira, SP, Brazil, both used as activators. The accelerators dibenzothiazole disulfide was provided by Shandong Shanxian Chemical Co. Ltd., Shanxian, Shandong Province, China and tetramethylthiuram monosulfide was purchased from Zhejiang Huangyan Zhedong Rubber Auxiliary Co., Ltd., Huangyan Laobei Road, Zhejiang Province, China. The cure agent, sulfur, was supplied by Jand Chemistry Industry and Commerce of Products Chemistry Ltda, Jandira, SP, Brazil. Paraffinic oil was purchased from FRAGON Products for rubber industry.

\section{Composites preparation}

The residue was previously milled to reduce the particle size. After, the clay brick waste was dried in an oven for $24 \mathrm{~h}$ at $80{ }^{\circ} \mathrm{C}$ and sieved into 170 mesh to obtain fine particles (around $88 \mu \mathrm{m}$ ). The composites were produced by mixing $\mathrm{CB}$ waste into the polymer matrix of natural rubber, varying residue ratios of 10-40 parts per hundred rubber (phr). To carry out the comparison, a sample of vulcanized natural rubber without filler was prepared. The mixture was prepared in two stages in an open chamber mixer (Makintec, model 379) with a friction ratio of 1.0:1.25. The curing agents are given in Table 1.

Table 1. Composites formulation (phr).

\begin{tabular}{|c|c|c|c|c|c|}
\hline \multirow{2}{*}{ Materials } & \multicolumn{5}{|c|}{ Composites Formulation } \\
\hline & NR & $\mathrm{NR} / \mathbf{C B}_{10}$ & $\mathrm{NR} / \mathbf{C B}_{\mathbf{2 0}}$ & $\mathrm{NR} / \mathbf{C B}_{\mathbf{3 0}}$ & $\mathrm{NR} / \mathrm{CB}_{40}$ \\
\hline Natural Rubber (NR) & 100 & 100 & 100 & 100 & 100 \\
\hline Stearic Acid & 2.0 & 2.0 & 2.0 & 2.0 & 2.0 \\
\hline Oxide Zinc & 5.0 & 5.0 & 5.0 & 5.0 & 5.0 \\
\hline Paraffinic Oil & 3.5 & 3.5 & 3.5 & 3.5 & 3.5 \\
\hline Clay Brick Waste (CB) & 0 & 10 & 20 & 30 & 40 \\
\hline $\mathrm{MBTS}^{\mathrm{a}}$ & 0.17 & 0.17 & 0.17 & 0.17 & 0.17 \\
\hline $\mathrm{TMTM}^{\mathrm{b}}$ & 0.46 & 0.46 & 0.46 & 0.46 & 0.46 \\
\hline Sulfur & 1.0 & 1.0 & 1.0 & 1.0 & 1.0 \\
\hline
\end{tabular}

${ }^{\mathrm{a}}$ Dibenzthiazyl disulphide; ${ }^{\mathrm{b}}$ Tetramethylthiuram monosulfide 
In the first stage, the natural rubber was processed by 10 minutes around $65{ }^{\circ} \mathrm{C}$. Then, zinc oxide and stearic acid, the vulcanization activators, were added and stirred for approximately 15 minutes until complete homogenization. Moreover, after the first stage completion, samples were stored at room temperature for 24 hours to allow the formation of zinc stearate that promote the reaction between the accelerators and curing agent. After that, the second stage begins with the incorporation of paraffinic oil, clay brick waste, the accelerators Dibenzothiazole disulfide and Tetramethylthiuram monosulfide and sulfur. The homogenization process was carried out around 25 minutes, with 5 minutes for each additive.

\section{MATERIALS CHARACTERIZATION}

The samples were vulcanized in a rheometer from Team Equipment Ltda, Brazil, with oscillating disk $1^{\circ}$ and isothermal temperature at $150{ }^{\circ} \mathrm{C}$ in accordance with ASTM D 2084 (ASTM, 2012). The mechanical properties were evaluated in triplicates. The abrasion resistance test was performed with a cylindrical sample with diameter of $16.0 \pm 0.2 \mathrm{~mm}$ and thickness of 6.0 $\mathrm{mm}$ in a rotating cylinder from MAQTEST, with frequency rotation of 40 cycles min-1, according to ASTM D 5963 (ASTM, 2010). The cylinder has a diameter of $150 \mathrm{~mm}$ with nominal distance for abrasion of 40 meters and abrasive paper with P60 grit size and aluminum oxide grain. Hardness tests were performed using a Kiltler durometer graduated in Shore A scale, according to the ASTM D 2240 standard (ASTM, 2010). The strain-stress test was investigated in type $C$ samples using a universal testing machine EMIC model DT500 at $500 \mathrm{~mm}$ min-1 with load cell of $100 \mathrm{kgf}$, to analyze the strength and elongation at break according to ASTM D-412 (ASTM, 2013).

The microscopic images were obtained by a scanning electron microscope (SEM, ZEISS, Model EVO LS15). A gold deposition was previously performed on the samples by Sputter in a Quorum Equipment, Model Q150TE. The particles sizes were measured using ImageJ @ program.X-ray fluorescence was performed by Dairix company with a Rigaku equipment, model Supermini 200 and power of $200 \mathrm{~W}$.

The structural characterization of the elastomers composites was studied by Fourier Transform Infrared Spectroscopy (FTIR), in the region of 4000-500 cm-1, with an accuracy of $2 \mathrm{~cm}-1$ and 24 scans, in a Bruker Model Vector 22 spectrophotometer. The composite surface was analyzed directly through the attenuated total reflectance (ATR) technique.

The crosslink density of the composites was evaluated by the swelling technique. First, the samples were weighed approximately $0.25 \pm 0.05 \mathrm{~g}$ and immersed in toluene for five days. Then, the samples were removed from toluene, surface-dried on absorbent paper, and weighed. Finally, the samples were dried in an oven at $60{ }^{\circ} \mathrm{C}$ for $24 \mathrm{~h}$ and weighed again. The crosslink density was calculated according to Equation (1), by FloryRehner method (Vieyres, 2013) and (Flory, 1943).

$$
\frac{1}{(2 \mathrm{Mc})}=\frac{-\left(\ln (1-V b)+V b+X(V b)^{2}\right)}{(p b)\left(V_{0}\right)\left(V b^{\frac{1}{3}}-\frac{V b}{2}\right)}
$$

where $\mathrm{Vb}$ is the volume fraction of the polymer in the swollen gel at equilibrium, $\mathrm{X}$ is the polymer-solvent interaction parameter, $\mathrm{pb}$ is the density of the polymer, and $\mathrm{VO}$ is the molar volume of the solvent.

\section{RESULTS AND DISCUSSIONS}

Table 2 presents the chemical components of $\mathrm{CB}$ waste analyzed by X-Ray Fluorescence. A typical composition of sedimentary clay which is used to produce red ceramics is observed. In accordance with the literature, there is a predominance of silicon and aluminum, in addition, the presence of calcium, iron, titanium and potassium (Pinheiro, 2010). Figure 1 shows SEM images of CB waste with 170 mesh where it is observed an agglomerate of fine particles with irregular profile and rough surface.

Table 3 shows the rheometric results. The increase of $\mathrm{CB}$ waste leads to a slight increase of the minimum (ML) and maximum torques (MH), but to a significant decrease in ts 2 and 190.

Table 2. Chemical components of CB waste analyzed by X-Ray Fluorescence.

\begin{tabular}{cc}
\hline \multicolumn{2}{c}{ X-Ray Fluorescence } \\
\hline Component & $\% \mathrm{~m} / \mathrm{m}$ \\
\hline $\mathrm{Si}$ & 55.90 \\
$\mathrm{Al}$ & 25.08 \\
$\mathrm{Fe}$ & 9.60 \\
$\mathrm{Ca}$ & 3.25 \\
$\mathrm{Ti}$ & 2.42 \\
$\mathrm{~K}$ & 2.07 \\
Others & 1.68 \\
\hline
\end{tabular}

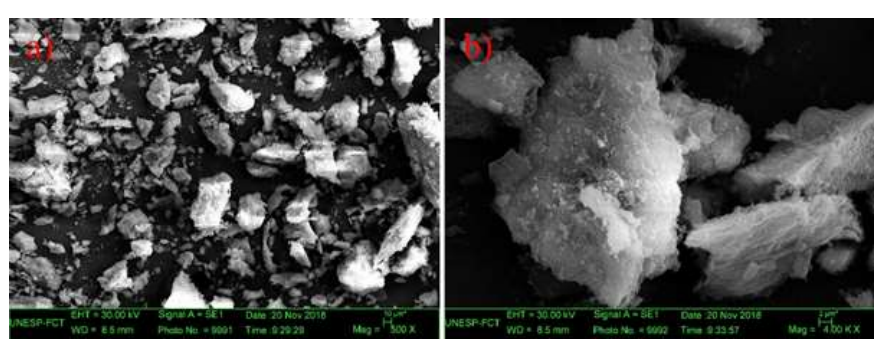

Fig. 1 Scanning electronic microscope (SEM) images of CB waste at amplifications of (a) 500X and (b) 4000X. 
Table 3. Rheometric parameters of NR compared to composites of NR with Clay Brick Waste (CB).

\begin{tabular}{lccccc}
\hline Samples & $\begin{array}{c}\mathbf{M}_{\mathbf{L}} \\
(\mathbf{d N . m})\end{array}$ & $\begin{array}{c}\mathbf{M}_{\mathbf{H}} \\
(\mathbf{d N . m})\end{array}$ & $\begin{array}{c}\Delta \mathbf{M} \\
(\mathbf{d N . m})\end{array}$ & $\begin{array}{c}\mathbf{t}_{\mathbf{s} 2} \\
(\mathbf{m i n})\end{array}$ & $\begin{array}{c}\mathbf{t}_{\mathbf{9 0}} \\
(\mathbf{m i n})\end{array}$ \\
\hline $\mathrm{NR}$ & 1.00 & 14.50 & 13.30 & 4.51 & 6.13 \\
$10 \mathrm{phr}$ & 1.00 & 13.10 & 12.10 & 3.25 & 4.50 \\
$20 \mathrm{phr}$ & 1.20 & 14.80 & 13.80 & 2.57 & 4.25 \\
$30 \mathrm{phr}$ & 1.20 & 15.10 & 13.90 & 2.34 & 4.01 \\
$40 \mathrm{phr}$ & 1.20 & 16.30 & 15.10 & 2.22 & 3.50 \\
\hline
\end{tabular}

Minimum torque presents a slight increment with the increase of filler loading, mainly for $20 \mathrm{phr}$, which indicates that the processability of the compounds becomes a little more difficult due to the enhanced viscosity and stiffness. In addition, this increase may be attributed to the agglomeration of filler particles in the polymeric matrix. For low loading mass, such as $10 \mathrm{phr}$, a better dispersion of the filler occurs, and the probability of aggregates formation is lower when compared to higher amounts of filler (Sareena, 2012).

Maximum torque increases with the increase of $\mathrm{CB}$ residue, mainly for $20 \mathrm{phr}$. The increase of maximum torque by the addition of the residue is an expected effect and is related to the increase of the stiffness of the polymeric matrix after vulcanization. This higher stiffness may be attributed to the presence of the residue and the formation of a higher number of cross-links (chemical or physical) (Escócio, 2003).

Crosslink density increases as the amount of clay brick waste is added to the samples, Fig. 2. The reduction in swelling when compared to natural rubber without waste evidence the interaction between rubber and the $\mathrm{CB}$ waste particles. However, compositions with 30 and $40 \mathrm{phr}$ of $\mathrm{CB}$ waste exhibit a decrease in properties, such as tensile strength and abrasion resistance, while crosslink density continuously increases. In this case, the enhancement of crosslink density with the increase of $\mathrm{CB}$ waste content has also been attributed to the restriction of rubber swelling caused by the filler and not effectively by the increase of crosslinking (Oliveira, 2014). The variation between the maximum and minimum torques $(\Delta \mathrm{M})$ indicates that the degree of reinforcement increases proportionally to the incorporation of the filler CB waste (Santos, 2014).

The reduction of ts 2 and $t 90$ can be related to the fact that $\mathrm{CB}$ waste behaved as a vulcanizing agent in natural rubber leading to an increase of the elastomer vulcanization rate. It may contribute to an earlier and faster process of natural rubber vulcanization when compared to natural rubber without waste. It means that in the industry, less energy is spent in the vulcanization process, saving costs (López-Manchado, 2003).

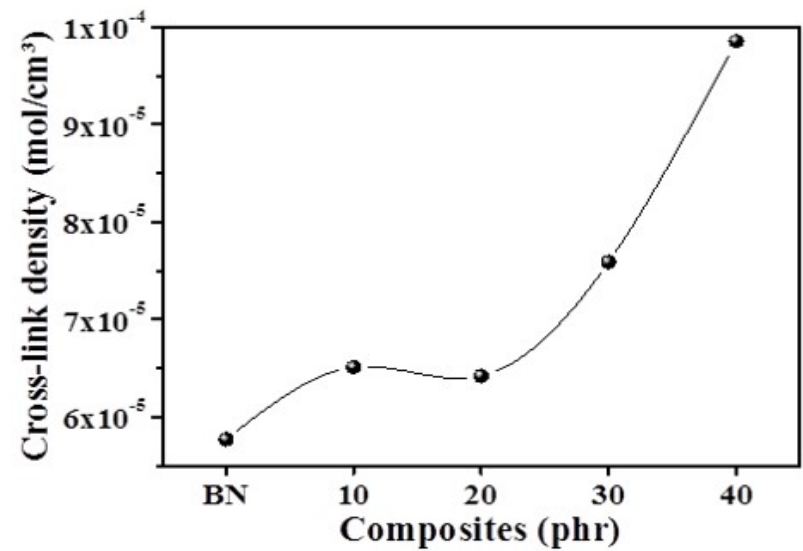

Fig. 2. Crosslink density of composites with Clay Brick waste.

Table 4 presents the values of tensile strength and strain at break of natural rubber and composites with $\mathrm{CB}$ residue. It is observed that natural rubber presents tensile strength value around $10.39 \mathrm{MPa}$ while composites with 10 and $20 \mathrm{phr}$ of residue show a reinforcement of the polymeric matrix reaching values around 11.23 and $12.41 \mathrm{MPa}$, respectively. This result indicates a suitable dispersion of the filler in the polymeric matrix. Composites with 30 and $40 \mathrm{phr}$ exhibit similar values to the natural rubber, 10.71 and $9.85 \mathrm{MPa}$, respectively. It can be attributed to the formation of aggregates, where the particle-particle interaction force, i.e., cohesion force, is greater than the interaction force between particle-polymer, also called cohesion (Navarro, 1997). A slight increase of the strain values at break is observed as an amount of waste is added until $30 \mathrm{phr}$. This is attributed to charge-load interactions, which cause uneven surface and volume in the composites and, consequently, increase hardness. On the other hand, it reduces tensile strength and deform the matrix.

Figure 3 shows the values of abrasion loss of natural rubber and composites with Clay Brick waste. Abrasion loss decreases with the addition of CB waste until 10 phr (168.22 mm3), increasing the abrasion resistance of the composites. This result can be attributed to the mechanical reinforcement of the filler and a well

Table 4. Tensile strength and strain values at break of natural rubber and composites with $\mathrm{CB}$ waste.

\begin{tabular}{ccc} 
Composites & $\begin{array}{c}\text { Tensile strength } \\
(\mathbf{M P a})\end{array}$ & $\begin{array}{c}\text { Strain at break } \\
(\mathbf{\%})\end{array}$ \\
\hline $\mathrm{NR}$ & $10.39 \pm 0.59$ & $681.00 \pm 37.00$ \\
$10 \mathrm{phr}$ & $11.23 \pm 0.80$ & $687.50 \pm 12.50$ \\
$20 \mathrm{phr}$ & $12.41 \pm 0.07$ & $712.50 \pm 12.50$ \\
$30 \mathrm{phr}$ & $10.71 \pm 0.05$ & $732.50 \pm 7.50$ \\
$40 \mathrm{phr}$ & $9.85 \pm 0.17$ & $725.00 \pm 0.00$ \\
\hline
\end{tabular}




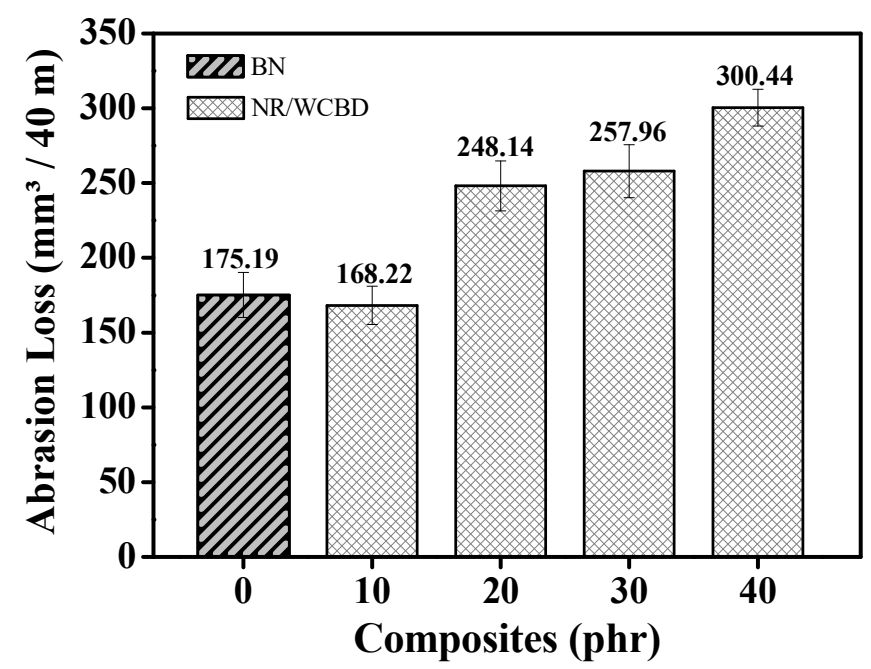

Fig. 3. Abrasion loss of NR and composites with Clay Brick waste.

dispersion of the residue particles that are embedded in the polymeric matrix. However, the enhancement of mass loss for $20 \mathrm{phr}(248.14 \mathrm{~mm} 3)$ is due to the generation of aggregates that create a tension surface on the composites and, consequently, decreases the abrasion resistance (Mousa, 2013).

Figure 4 shows the hardness values of natural rubber and composites. It is observed that the hardness values increase proportionally to the addition of $\mathrm{CB}$ residue. This is associated to the increase of cross-links formed during the vulcanization process (Santos, 2015) and the presence of inorganic compound in the $\mathrm{CB}$ waste residue with a rigid nature (Hundiwale, 2002).

Figure 5 presents the SEM images of composites incorporated with $\mathrm{CB}$ waste. As the waste concentration increases, the amount of dispersed particles of waste also increases, when compared to natural rubber without residue. FT-IR spectra of vulcanized natural rubber and the composite with $40 \mathrm{phr}$ of $\mathrm{CB}$ are demonstrated in Fig. 6. There is no evidence of new peaks that characteristic of composites with physical interaction.

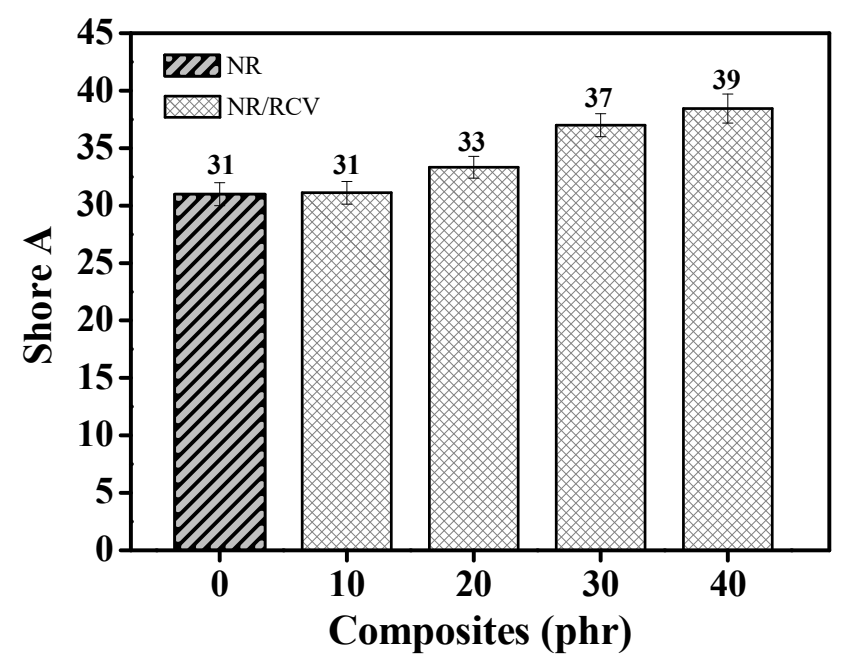

Fig. 4. Hardness of NR and composites with Clay Brick waste.
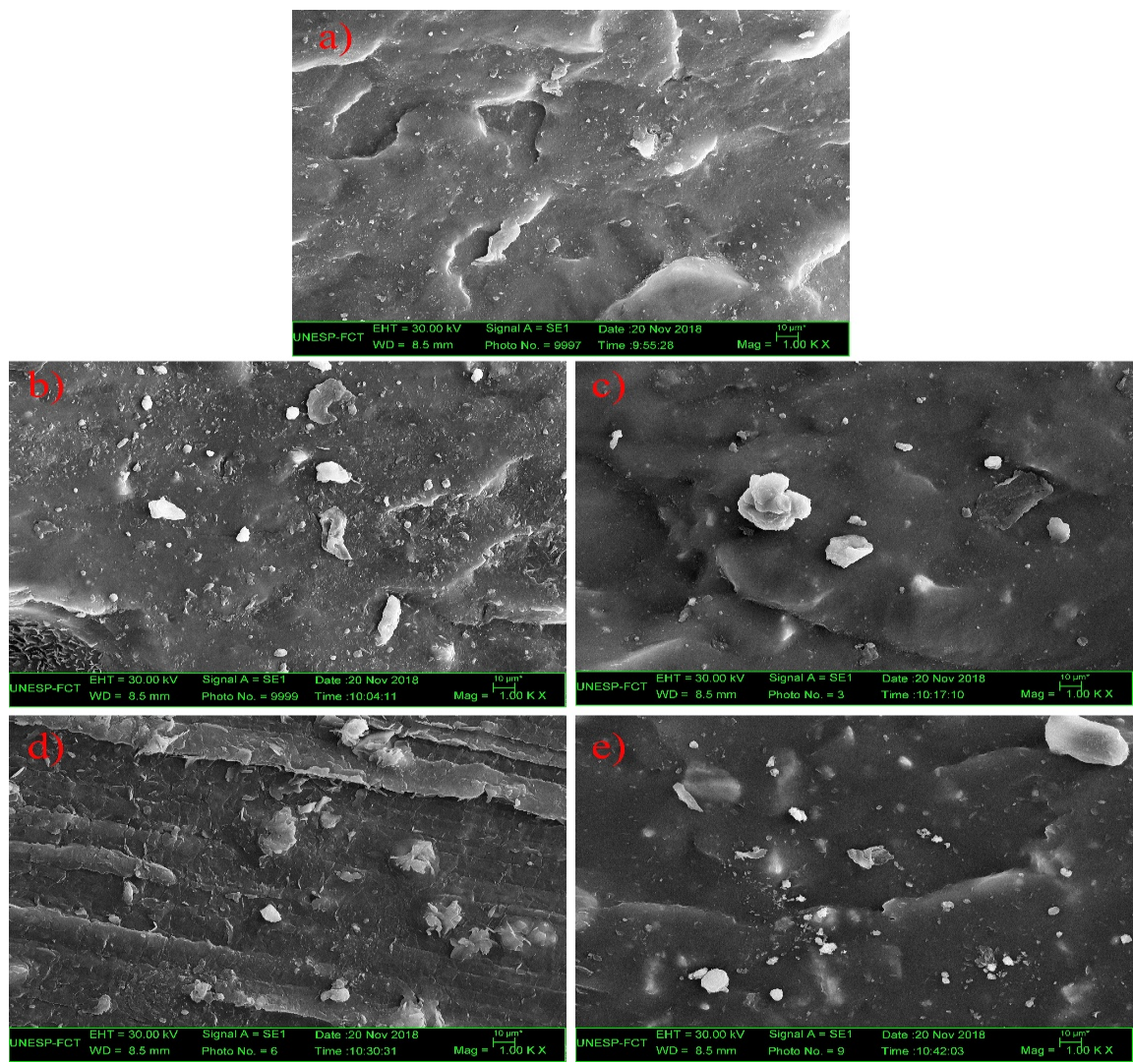

Fig. 5. Transversal section of SEM images of NR (a) and NR/CB $10 \mathrm{phr}$ (a), $20 \mathrm{phr}$ (b), $30 \mathrm{phr}$ (c) and $40 \mathrm{phr}$ (d). 


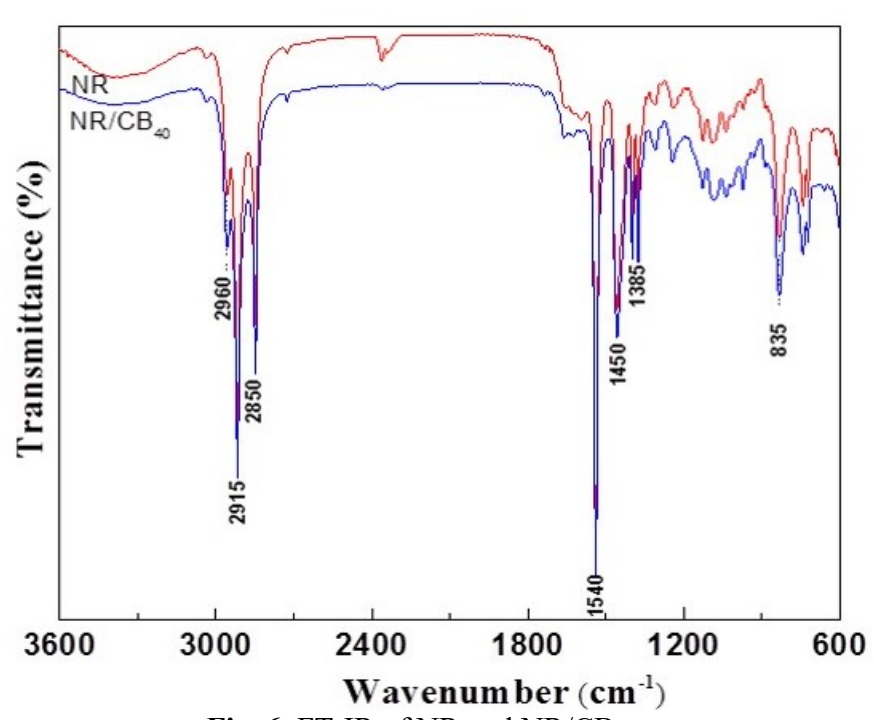

Fig. 6. FT-IR of NR and NR/CB $\mathrm{CB}_{40}$.

FT-IR spectra show three bands at $2960 \mathrm{~cm}-1,2915$ $\mathrm{cm}-1$ and $2850 \mathrm{~cm}-1$ attributed to $\mathrm{CH} 3$ asymmetric stretching modes, asymmetric stretching and symmetric vibrations of methyl groups, respectively (Agostini, 2008). The stretching of $\mathrm{C}=\mathrm{C}$ bonds is seen at $1540 \mathrm{~cm}-$ 1 and the band at $1450 \mathrm{~cm}-1$ is assigned to $\mathrm{CH} 3$ deformation mode. The functional groups of the rubber present bands between 1385 and $950 \mathrm{~cm}-1$. The region between $1385-1150 \mathrm{~cm}-1$ is attributed to the twisting and wagging of $\mathrm{CH} 2$ and the region between $1150 \mathrm{~cm}-1$ and $950 \mathrm{~cm}-1$ is assigned to $\mathrm{CH} 3$ rocking vibration of the unsaturated hydrocarbons. The presence of a band at $835 \mathrm{~cm}-1$ is attributed to $\mathrm{CH}$ out-of-plane bending (Dall'Antonia, 2009) and (Nallasamy, 2004).

\section{CONCLUSIONS}

The influence of $\mathrm{CB}$ waste addition in natural rubber was verified and demonstrated that clay bricks can be used as a filler. The decrease of ts 2 and 190 shows that $\mathrm{CB}$ waste contributes to the natural rubber vulcanization which starts earlier and it is faster when compared to the natural rubber without waste. The waste presents high concentration of silicon and its incorporation in the natural rubber contributes to the increase of tensile strength in $16 \%$ when $20 \mathrm{phr}$ is added. In addition, composites with $10 \mathrm{phr}$ of waste showed abrasion resistance higher than the natural rubber.

\section{REFERENCES}

Agostini, D.L.S., Constantino, C.J.L., Job, A.E. (2008). Thermal degradation of both latex and latex cast films forming membranes. Journal of Thermal Analysis Calorimetry, 91(3), 703-707. doi: 10.1007/s10973-007-8351-x.

Akhtar, A., Sarmah, A.K. (2018). Construction and demolition waste generation and properties of recycled aggregate concrete: a global perspective. J. Clean. Prod. 186, 262-281. doi: 10.1016/j.jclepro.2018.03.085.
Amin, M. S., El-Gamal, S. M. A., Hashem, F. S. (2015). Fire resistance and mechanical properties of carbon nanotubes-clay bricks wastes (Homra) composites cement. Construction and Building Materials, 98, 237-249. doi: 10.1016/j.conbuildmat.2015.08.074.

ASTM D 2084 Standard Test Method for Rubber Propert Vulcanization Using Oscillating Disk Cure Meter, ASTM International, (2012).

ASTM D 2240 Test Method for Rubber Property - Durometer Hardness, ASTM International; (2010).

ASTM D 412 Test Methods for Vulcanized Rubber and Thermoplastic Elastomers -Tension, ASTM International; (2013).

ASTM D 5963 Test Method for Rubber Property - Abrasion Resistance (Rotary Drum Abrader), ASTM International; (2010).

Barrera, C. S., Cornish, K. (2016). High performance waste-derived filler/carbon black reinforced guayule natural rubber composites. Industrial Crops and Products, 86, 132-142. doi: 10.1016/j.indcrop.2016.03.021.

C. Sareena, M. T. Ramesan, E. Purushothaman. (2012). Utilization of Peanut Shell Powder as a Novel Filler in Natural Rubber. Journal of Applied Polymer Science, 125(3), 2322-2334. doi: 10.1002/app.36468.

Cabrera, F. C., de Souza, J. C., Job, A. E., Crespilho, F. N. (2014). Natural-rubber-based flexible microfluidic device. Rsc Advances, 4(67), 35467-35475. doi: 10.1039/C4RA07458K.

Cabrera, F. C., Mohan, H., Dos Santos, R. J., Agostini, D. L., Aroca, R. F., Rodríguez-Pérez, M. A., Job, A. E. (2013). Green synthesis of gold nanoparticles with self-sustained natural rubber membranes. Journal of Nanomaterials, 2013, 1-10. doi: $10.1155 / 2013 / 710902$.

Chen, X., Wang, Z., Wu, J. (2018). Processing and characterization of natural rubber/stearic acid-tetra-needle-like zinc oxide whiskers medical antibacterial composites. Journal of Polymer Research, 25(2), 48. doi: 10.1007/s10965-017-1433-y.

Dall'Antonia, A.C., Martins, M.A., Moreno, R., Mattoso, L.H., Gonçalves, P.S., Job, A.E. (2009). - Borracha natural formulada e vulcanizada dos clones: GT 1, IAN 873, PB 235 e RRIM 600. Polímeros, 19(1), 63-71. doi: 10.1590/S010414282009000100015.

Dang, J., Zhao, J., Hu, W., Du, Z., Gao, D. (2018). Properties of mortar with waste clay bricks as fine aggregate. Construction and Building Materials, 166, 898-907. doi: 10.1016/j.conbuildmat.2018.01.109.

Dong, B., Zhang, L., Wu, Y. (2016). Highly conductive natural rubber-graphene hybrid films prepared by solution casting and in situ reduction for solvent-sensing application. Journal of materials science, 51(23), 10561-10573. doi: 10.1007/s10853-016-0276-y.

Escócio, V.A., Martins, A.F., Visconte, L.L.Y., Nunes, R.C.R., Costa, D.M.R. (2003). Influência da Mica nas Propriedades Mecânicas e Dinâmico-Mecânicas de Composições de Borracha Natural. Polímeros: Ciência e Tecnologia, 13(2), 130-134. doi: 10.1590/S0104-14282003000200012.

Essabir, H., Nekhlaoui, S., Bensalah, M. O., Rodrigue, D., Bouhfid, R., el kacem Qaiss, A. (2017). Phosphogypsum waste used as reinforcing fillers in polypropylene based composites: Structural, mechanical and thermal properties. Journal of Polymers and the Environment, 25(3), 658-666. doi: 10.1007/s10924-016-0853-9.

Fiore, V., Di Bella, G., Scalici, T., Valenza, A. (2018). Effect of plasma treatment on mechanical and thermal properties of marble powder/epoxy composites. Polymer Composites, 39(2), 309-317. doi: 10.1002/pc.23937.

Flory, P.J., Rehner, Jr. J.J. (1943). Statistical Mechanics of Cross-Linked Polymer Networks II. Swelling. The Journal of Chemical Physics, 11, 521-526. doi.org/10.1063/1.1723792.

Garcia, N. G., dos Reis, E. A. P., Budemberg, E. R., Agostini, D. L. D. S., Salmazo, L. O., Cabrera, F. C., Job, A. E.. (2015). Natural rubber/leather waste composite foam: A new eco-friendly 
material and recycling approach. Journal of Applied Polymer Science, 132(11), 1-10. doi: 10.1002/app.41636.

Hawkes, E. W., Christensen, D. L., Okamura, A. M. (2016). Design and implementation of a $300 \%$ strain soft artificial muscle. In: 2016 IEEE International Conference on Robotics and Automation (ICRA) (pp: 4022-4029). Stockholm, Sweden: IEEE. doi: 10.1109/ICRA.2016.7487592.

Huang L, Wang P. (2017). Effects of preparation conditions on properties of rigid polyurethane foam composites based on liquefied bagasse and jute fiber. Polymer Testing, 60, 266-273. doi: 10.1016/j.polymertesting.2017.04.006.

Hundiwale, G., Kapadi, U.R., Desai, M.C., Bidkar, S.H. (2002). Mechanical Properties of Natural Rubber Filled with Flyash. Journal of Applied Polymer Science, 85(5), 995-1001.doi: 10.1002/app.10465.

López-Manchado, M. A., Arroyo, M., Herrero, B., Biagiotti, J. (2003). Vulcanization Kinetics of Natural Rubber-Organoclay Nanocomposites. Journal of Applied Polymer Science, 89(1), 115. doi: 10.1002/app.12082.

Mohammed, T. U., Das, H. K., Mahmood, A. H., Rahman, M. N., \& Awal, M. A. (2017). Flexural performance of RC beams made with recycled brick aggregate. Construction and Building Materials, 134, 67-74, 2017.doi: 10.1016/j.conbuildmat.2016.12.135.

Monier, V., Mudgal, S., Hestin, M., Trarieux, M., Mimid, S. (2011). Management of Construction and Demolition Waste [WWW Document]. URL. (Accessed 17 November 2018). http://ec.europa.eu/environment/waste/pdf/2011_CDW_Report.pd f.

Mousa, A., Heinrich, G., Wagenknecht, U. (2013). The application of solid olive waste as reinforcement in carboxylated nitrile butadiene rubber/organo nano layered silicates composites. Journal of Solid Waste Technology and Management, 39(3), 197203 doi: 10.5276/JSWTM.2013.197.

Nallasamy, P., Mohan, S. (2004). Vibrational spectra of cis-1, 4 polyisoprene. Arabian Journal Science. Engineering. 29(1), 17-26.

Navarro, R.F. (1997). Fundamentos de reologia de polímeros. Caxias do Sul: EDUCS.

NBR 1004- Resíduos sólidos - classificação, Rio de Janeiro, 2004, $77 \mathrm{p}$.

Novais, R. M., Carvalheiras, J., Seabra, M. P., Pullar, R. C., Labrincha, J. A. (2017). Effective mechanical reinforcement of inorganic polymers using glass fibre waste. Journal of Cleaner Production, 166, 343-349. doi: 10.1016/j.jclepro.2017.07.242.

Oliveira, M.A.S., Cassu, S.N., Mello, S.A., Dutra, J.C.N. (2014). Influência do teor de negro de fumo nas propriedades dinâmicomecânicas de borracha natural. In $21^{\circ} \mathrm{CBECIMAT} \mathrm{-} \mathrm{Congresso}$ Brasileiro de Engenharia e Ciência dos Materiais. Cuiabá.

Paiva, F. F. G., de Maria, V. P. K., Torres, G. B., Dognani, G., dos Santos, R. J., Cabrera, F. C., Job, A. E. (2018) Sugarcane bagasse fiber as semi-reinforcement filler in natural rubber composite sandals. Journal of Material Cycles and Waste Management, 21(2), 326-335. doi: 10.1007/s10163-018-0801-y.
Patnaik, P. K., Biswas, S. (2018). Effect of blast furnace slag content on mechanical and slurry abrasion behavior of needle-punched nonwoven fabric reinforced epoxy composites. Advances in Polymer Technology, 37(6), 1764-1773. doi: 10.1002/adv.21835.

Pinheiro, B.C.A., Holanda, J. N. F. (2010). Efeito da temperatura de queima em algumas propriedades mecânicas de cerâmica vermelha. Cerâmica, 56(339), 237-243. doi: 10.1590/S036669132010000300005

Pittayavinai P, Thanawan S, Amornsakchai T. (2016). Manipulation of mechanical properties of short pineapple leaf fiber reinforced natural rubber composites through variations in cross-link density and carbon black loading. Polymer Testing, 54, 84-89. doi: 10.1016/j.polymertesting.2016.07.002.

Pongdong, W., Kummerlöwe, C., Vennemann, N., Thitithammawong, A., Nakason, C. (2016). Property correlations for dynamically cured rice husk ash filled epoxidized natural rubber/thermoplastic polyurethane blends: Influences of RHA loading. Polymer Testing, 53, 245-256. doi: 10.1016/j.polymertesting.2016.05.026.

R.J. Santos, D.L.S. Agostini, F.C. Cabrera, E.A.P. Reis, M.R. Ruiz, E.R. Budemberg, S.T. Rainho, A.E. Job. (2014). Sugarcane Bagasse Ash: New Filler to Natural Rubber Composite. Polímeros, 24(6), 646-653. doi: 10.1590/0104-1428.1547.

Robayo-Salazar, R. A., Mejía-Arcila, J. M., \& de Gutiérrez, R. M. (2017). Eco-efficient alkali-activated cement based on red clay brick wastes suitable for the manufacturing of building materials. Journal of Cleaner Production, 166, 242-252. doi: 10.1016/j.jclepro.2017.07.243.

Santos, R.J., Agostini, D.L.S., Cabrera, F.C., Budemberg, E.R., Job, A.E. (2015). Recycling leather waste: Preparing and studying on the microstructure, mechanical, and rheological properties of leather waste/rubber composite. Polymer Composites, 36(12), 2275-2281. doi: 10.1002/pc.23140.

Väntsi, O., Kärki, T. (2014). Utilization of recycled mineral wool as filler in wood-polypropylene composites. Construction and Building Materials, 55, 220-226. doi: 10.1016/j.conbuildmat.2014.01.050.

Vieyres, A., Aparicio, R.P., Albouy, P.A., Sanseau, O., SaalwäChter, K., Long, D.R., Sotta, P. (2013). Sulfur-Cured Natural Rubber Elastomer Networks: Correlating Cross-Link Density, Chain Orientation, and Mechanical Response by Combined Techniques. Macromolecules, 46(3), 889-899. doi: 10.1021/ma302563z.

Zefeng, W., Yong, K., Zhao, W., Yi, C. (2018). Recycling waste tire rubber by water jet pulverization: powder characteristics and reinforcing performance in natural rubber composites. Journal of Polymer Engineering, 38(1), 51-62. doi: 10.1515/polyeng-20160383.

Zong, L., Fei, Z., Zhang, S. Permeability of recycled aggregate concrete containing fly ash and clay brick waste. Journal of Cleaner Production, 70, 175-182. doi: 10.1016/j.jclepro.2014.02.040.. 